Research paper

\title{
Forest cover dynamics of the Bazoy Siberian pine (Pinus sibirica Du Tour) forest from 1915 to 2015
}

\author{
Nikita Debkov ${ }^{1,2^{*}}$, Victor Sidorenkov ${ }^{3}$, Elena Sidorenkova ${ }^{3}$ and \\ Vladimir Sedykh ${ }^{4}$
}

Debkov, N., Sidorenkov, V., Sidorenkova, E., Sedykh, V. 2020. Forest cover dynamics of the Bazoy Siberian pine (Pinus sibirica Du Tour) forest from 1915 to 2015. - Forestry Studies | Metsanduslikud Uurimused 73, 52-63, ISSN 1406-9954. Journal homepage: http:/ / mi.emu. ee/forestry.studies

\begin{abstract}
The article considers the long-term (100 years) dynamics of the forest cover of the southernmost unit of Siberian pine forests on the West Siberian plain. A key feature of forest management is that Siberian pine seeds are a valuable food product and, when cutting forests, this tree species, as a rule, is preserved. The basis of the experimental data was the material of the national forest inventories of 1915, 1974 and 2015 for a total area of 1,420.41 ha. During the period from 1915 to 2015, the forested area changed slightly (96.2 and $94.0 \%)$, while the share of Siberian pine stands increased significantly from 48.4 to $58.7 \%$. Grassy Siberian pine forests (32.1\%) of optimal age (120-140 years), which are characterised by the best seed productivity and the largest share of Siberian pine in the community $(77 \%)$, predominate. Basically, human economic activity results in an increase in the area of Siberian pine stands, when deciduous stands with Siberian pine undergrowth are used for fuel and as building material. A decrease in the area of Siberian pine forests occurs mainly under the impact of fires. In the conflagrations of 1915-1920, 7 to $38 \%$ of silver birch forests have no Siberian pine undergrowth and are considered long-term secondary communities. In the remaining area, the proportion of Siberian pine undergrowth is $20-30 \%$ with a density of $800-1200$ seedlings ha-1, which is sufficient for the natural formation of Siberian pine forests.
\end{abstract}

Key words: forest maps, woodland dynamics, forest gain, forest loss, Western Siberia.

Author's addresses: ${ }^{1}$ Laboratory of Monitoring of Forest Ecosystems, Institute of Monitoring of Climatic and Ecological Systems, Academichesky ave. 10/3, 634055, Tomsk, Russia; ${ }^{2}$ Biological Institute, Tomsk State University, Lenina ave. 36, 634050, Tomsk, Russia; ${ }^{3}$ Department of Silviculture and Forest Inventory, All-Russian Research Institute for Silviculture and Mechanization of Forestry, Institutskaya str. 15, 141202, Pushkino, Moscow region, Russia; ${ }^{4}$ West Siberian of the Sukachev Institute of Forest, Zhukovsky str. 100/1, 630082, Novosibirsk, Russia; "e-mail: nikitadebkov@yandex.ru

\section{Introduction}

The goals of the United Nations Declaration (2000) state the critical link between forests and sustainable development. The area of forest cover is one of the indicators for the 7th goal "to ensure environmental sustainability". Forest cover dynamics is recognised as one of the most pressing environmental problems in the world (Yang \& Mountrakis, 2017; Kundu, 2017). A complex combination of economic and social

DOI: $10.2478 /$ fsmu-2020-0014

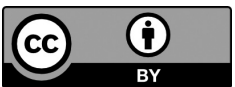

() 2020 by the authors. Licensee Estonian University of Life Sciences, Tartu, Estonia. This article is an open access article distributed under the terms and conditions of the Creative Commons Attribution (CC BY) license (http:/ / creativecommons.org/licenses/ by $/ 4.0 /)$. 
development factors, agricultural productivity levels and urbanisation, climatic conditions and geographical features, as well as historical factors, together determine the rate of deforestation (Lambin et al., 2003; Luoga et al., 2005). However, of course, human activity is the dominant cause of modern environmental change around the world (Lewis \& Maslin, 2015). Moreover, for example, over the analyzed 336-year period, a model site in Switzerland (Loran et al., 2018) established an unambiguous link between deforestation and political and economic crises.

With the advent of remote sensing, large-scale studies of deforestation have been feasible since 1972 (Skole \& Tucker, 1993). Numerous studies have shown the promise of remote sensing for assessing the dynamics of forest cover (Selvaraj et al., 2013; Reddy et al., 2013; Da Ponte et al., 2017; Thayamkottu \& Joseph, 2018). How- ever, using existing indicators, mainly landscape indices, it is not always possible to obtain reliable data (Haines-Young \& Chopping, 1996; Li \& Wu, 2004; Dramstad, 2009). Earlier reconstructions (Lin et al., 2017) are possible only with the availability of forest inventory data and other archival materials. Thus, at the present stage of the development of science, empirical studies of the dynamics of local forests are still relevant and important for solving complex problems of human-environmental interaction (Jadin et al., 2013).

In this context, the goal of our work is to assess the dynamics of the Bazoy Siberian pine (Pinus sibirica Du Tour) forest (BSPF) from 1915 to 2015, located (1) on the southern border of the distribution of Siberian pine in Western Siberia and (2) subjected to intense anthropogenic impact for over 400 years.

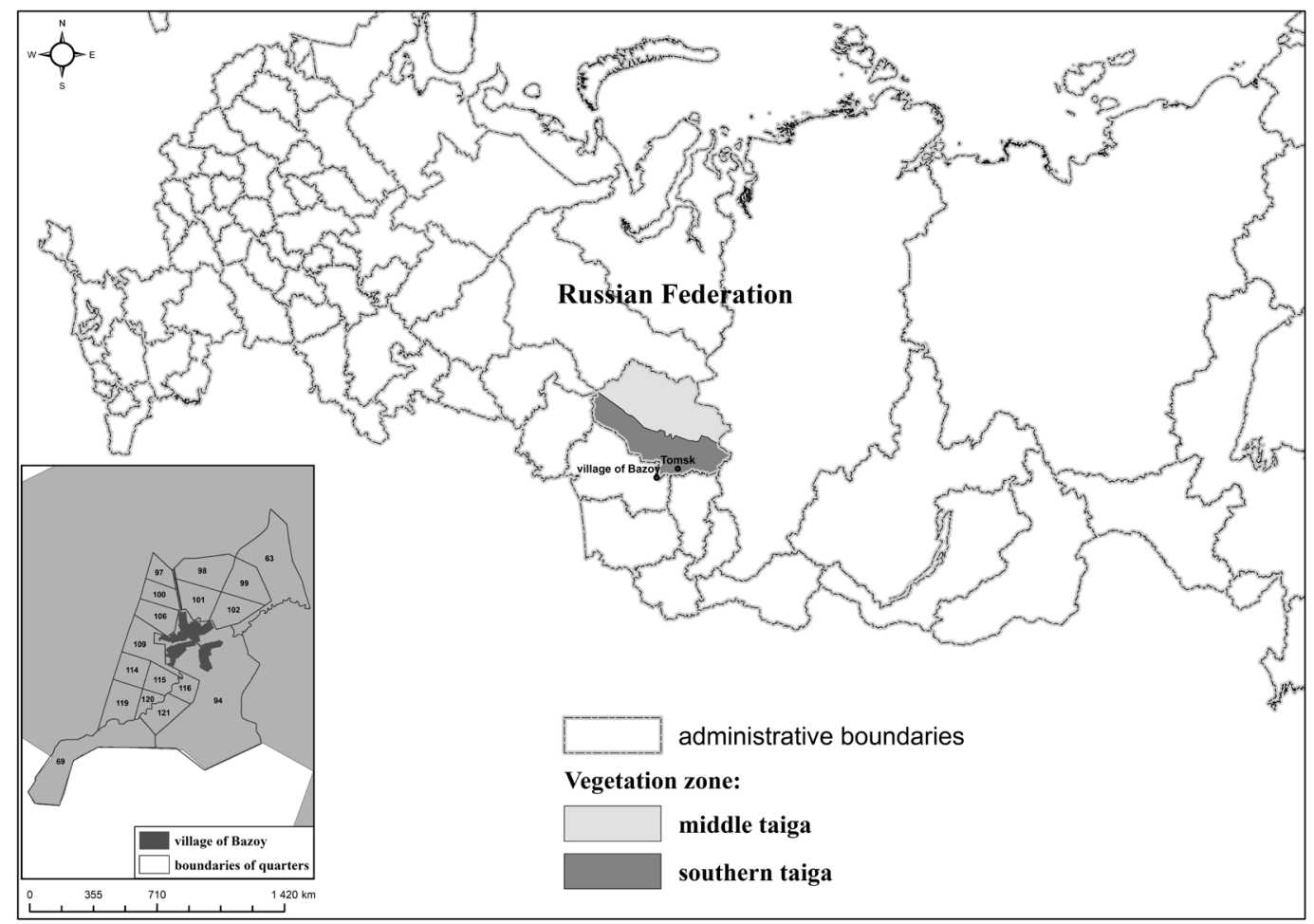

Figure 1. Study area. 


\section{Material and Methods}

\section{Study area}

The BSPF is located in the vicinity of the village of Bazoy (Figure 1), which was founded in 1575. The village is located in the south of the Tomsk region, $190 \mathrm{~km}$ from the capital of the region. According to the Köppen-Geiger climate classification (Kottek et al., 2006), the climate in the study area is humid continental (Dfb index - D (Continental), f (No dry season), b (Warm summer)). The average annual temperature is $0.8^{\circ} \mathrm{C}$, with an average precipitation of $466 \mathrm{~mm}$. The relief is flat, with small differences in elevation of up to $2-3 \mathrm{~m}$. The Kinda river flows through the territory and into the Siman Channel, the left tributary of the Ob River. The BSPF is confined to the border of the taiga and forest-steppe and is the largest preserved forest unit of Siberian pine forests on the southern limit of their distribution in the West Siberian plain. The main forest-forming species are Siberian pine Pinus sibirica Du Tour, Siberian spruce Picea obovata Ledeb., silver birch Betula pendula Roth. and white birch B. pubescens Ehrh. However, common Scots pine Pinus sylvestris L. and aspen Populus tremula L. are also common.

It should be noted that Siberian pine is a nut-bearing tree species. From the beginning of the colonisation of Siberia by the Russian people, the beneficial and nutritional properties of Siberian pine nuts have been noted (Danchenko \& Bekh, 2010). Therefore, the local population sought to create nut (seed) orchards with a predominance of Siberian pine near their villages (Debkov, 2014). As a rule, Siberian pine trees were left during felling, while the remaining tree species were cut down, resulting in the formation of Siberian pine seed orchards (Debkov, 2019).

\section{Data}

The experimental data are based on the materials of the national forest inventories of 1915, 1974 and 2015, carried out on the ter- ritory of the BSPF. In Russia, on the plains, the division of the forest fund within the forestry boundaries (the subject of forest management) into small, usually rectangular or square, sections (quarters) was used. Most quarters were $1 \times 1,1 \times 2,2 \times 2$ or $2 \times 4 \mathrm{~km}$ in size, and each was assigned an identification number. We analysed 14 quarters on a total area of 1,420.41 ha. Within the boundaries of each quarter, elementary units (plots) were distinguished - forest stands and other land categories, in accordance with approved regulatory documents (for example, forest inventory instruction). Regardless of the size of the quarter, it contained several dozens of plots. In our case, 293 plots were analysed. When conducting forest inventories, each plot was evaluated in terms or more than 10 indicators. In forest stands, the composition, age, height, diameter, type of forest, sum of basal areas and stand volume were determined visually and with the help of instruments. Natural regeneration (composition, height, age, density) was also described.

\section{Data analysis}

The initial data for digitisation consisted of raster forest maps of 1915, 1974 and 2015 and vector data of the quarterly network of the Tomsk region. These data were obtained from forest inventories and a previous publication (Alekseev \& Sedykh, 1976). Digitisation was carried out using the Easy Trace vectorizer version 9.5 (Digitization of vegetation, 2011). Preliminary georeferencing of forest maps was performed at reference points in the geographic information system software package of the Arcgis Desktop 10.4 (Mitchell, 2005); by means of automatic and manual tracing, vector layers of forest maps were created with the assignment of the corresponding attribute information. Further, by arranging the pages (sets of layer elements located on the virtual page, including the legend) in Arcgis Desktop 10.4 (Keranen \& Malone, 2017), the ready-made forest maps of 1915, 1974 and 2015 were exported into jpeg files. 
Statistical analysis of our data was carried out using the STATISTICA 10 program. We used the standard descriptive statistics (mean \pm standard error) with a level of $p<0.05$.

\section{Results}

The spatial structure of the Bazoy Siberian pine forest and its dynamics

The forest cover as of 1915 (Figure 2, Table 1) was a forested area $(96.2 \%)$, with Siberian pine forests occupying $48.4 \%$. Wetlands accounted for only $3.8 \%$ of the total area. In 1974, the ratio of land categories remained virtually unchanged (Figure 2, Table 1). The area on which forest stands grew was $96.1 \%$, and the area occupied by wetlands was 3.9\% (an additional area of 1.4 hectares was allocated in Quarter 102). However, there was a change in the area of Siberian pine forests, which increased their share to $64.7 \%$, that is, by $16.3 \%$. The most sig- nificant changes occurred in Quarters 98, 99, 101 and 102, where the area of Siberian pine forests increased. On the contrary, in Quarters 109, 114, 115, 116, 119 and 120, the area of Siberian pine forests decreased. However, overall, the balance was positive throughout the BSPF. The state of the forest cover as of 2015 (Figure 2, Table 1) is characterised by a decrease in the share of wetlands $(2.3 \%)$, but a new category of land has appeared - non-forest areas (3.7\%), which include glades, wasteland and hayfields. In this regard, the forested area decreased slightly (94.0\%). The area occupied by Siberian pine forests decreased to $58.7 \%$, that is, by $6.0 \%$ compared to 1974 . Spatially, there have been serious changes in the location of the wetlands, most of which were reallocated in Quarters 97, 99, 100, 106 and 114. In the quarters in which the wetlands were located previously, they had either disappeared or significantly reduced in terms of area. Non-forest areas were mainly prevalent in Quarters 98, 101,

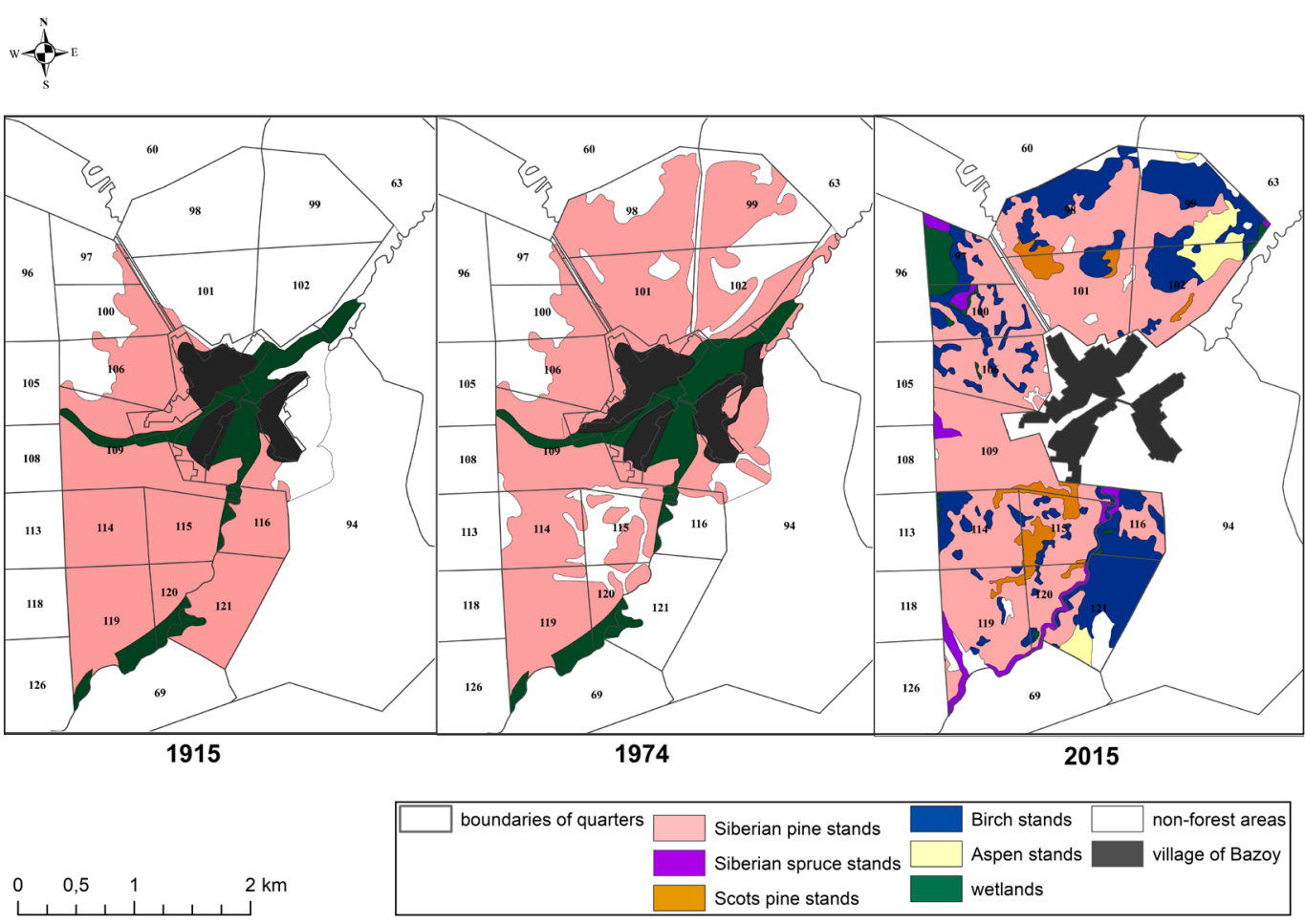

Figure 2. State of forest cover of the Bazoy Siberian pine forest in 1915, 1974, 2015. 
119 and 121. A positive dynamic in increasing the area of Siberian pine forests was observed only in Quarter 102, albeit this was not statistically significant. The area of Siberian pine forests began to increase in Quarters 97, 100 and 106. After a decrease in 1974, an increase in the share of Siberian pine stands in Quarters 109, 115, 116 and 120 was recorded, while in Quarters 114, 119 and 121, the Siberian pine forest area steadily decreased. In Quarters 98, 99 and 101 , there is a slight decrease in the area of Siberian pine forests relative to 1974 .

Table 1. Distribution of the Bazoy Siberian pine forest by land categories (ha).

\begin{tabular}{lccccccccccccc}
\hline & \multicolumn{3}{c}{ Wetlands } & \multicolumn{4}{c}{ Non-forest areas } & \multicolumn{3}{c}{ Non-Siberian pine } & \multicolumn{3}{c}{ Siberian pine stands } \\
\cline { 2 - 13 } & 1915 & 1974 & 2015 & 1915 & 1974 & 2015 & 1915 & 1974 & 2015 & 1915 & 1974 & 2015 \\
\hline 97 & - & - & 21.4 & - & - & - & 54.9 & 54.9 & 16.3 & 5.8 & 5.8 & 22.8 \\
98 & - & - & - & - & - & 10.5 & 161.2 & 46.6 & 63.4 & 0.7 & 115.2 & 85.9 \\
99 & - & - & 1.4 & - & - & 2.9 & 139.0 & 61.6 & 84.2 & - & 77.4 & 39.6 \\
100 & - & - & 5.9 & - & - & 0.01 & 52.3 & 52.3 & 26.3 & 25.8 & 25.8 & 45.8 \\
101 & - & - & - & - & - & 10.1 & 121.4 & 15.6 & 24.1 & 5.3 & 111.14 & 92.3 \\
102 & - & 1.4 & 1.0 & - & - & 0.5 & 117.2 & 53.4 & 50.9 & - & 62.3 & 64.6 \\
106 & - & - & 0.6 & - & - & 2.9 & 36.5 & 36.5 & 16.6 & 63.4 & 63.4 & 79.8 \\
109 & 15.7 & 15.7 & - & - & - & 0.5 & 2.3 & 8.6 & 13.3 & 125.7 & 119.4 & 129.8 \\
114 & - & - & 1.0 & - & - & - & - & 17.0 & 25.6 & 92.7 & 75.7 & 66.1 \\
115 & 4.7 & 4.7 & - & - & - & - & - & 37.8 & 32.6 & 73.6 & 35.8 & 45.8 \\
116 & 1.7 & 1.7 & 1.0 & - & - & - & - & 52.3 & 36.2 & 57.0 & 4.7 & 21.5 \\
119 & 18.1 & 18.1 & - & - & - & 11.4 & - & 2.3 & 23.6 & 114.1 & 111.7 & 97.3 \\
120 & 8.2 & 8.2 & 0.6 & - & - & - & - & 10.4 & 11.5 & 34.8 & 24.4 & 30.9 \\
121 & 6.5 & 6.5 & - & - & - & 13.7 & - & - & 76.0 & 95.9 & 95.9 & 12.2 \\
\hline Sum & 55.0 & 56.4 & 32.9 & 0.0 & 0.0 & 52.5 & 684.6 & 449.4 & 500.5 & 694.7 & 928.6 & 834.4 \\
\hline
\end{tabular}

Stand structure and other land categories of the Bazoy Siberian pine forest

In the modern forest cover of the BSPF, grassy Siberian pine stands $(32.1 \%$, Figure 3 ) of optimal age (120-140 years) prevail, which are characterised by the best seed productivity and the largest share of Siberian pine trees in the composition of communities (77\%, Table 2). Old-aged Siberian pine forests (over 140 years old) occupy $17.4 \%$; in the medium term, they will be damaged, including during entomogenic successions (Krivets et al., 2014), and gradually replaced by other forest-forming species, which is indirectly confirmed by a decrease in the abundance of Siberian pine in the composition communities of up to $67 \%$. Young Siberian pine forests (up to 120 years old), starting to provide good nut harvests, are present on an area of $8.9 \%$, with a share of Siberian pine trees in the stands of $66 \%$. Siberian pine forests of the grassy-swamp forest type occupy a limited area $(4.6 \%)$ and have a narrower age structure (130-160 years) compared to the grassy Siberian pine stands, which occur from 110 to 190 years of age. They are distinguished by a low proportion of Siberian pine trees in the composition of the communities, which ranges from $44-46 \%$. This also indicates that the local population practically does not establish nut (seed) orchards in them. After Siberian pine forests, silver and white birch stands occupy 
the largest area (19.7 and $8.7 \%$ of the grassy and grassy-swamp forest type). The age fluctuation is the same, ranging from 55-85 years, that is, silver and white birch forests belong to mature stands and are suitable for cutting. Siberian spruce forests are represented only by the grassy-swamp forest type, which is typical of the southern taiga subzone and occupies $2.9 \%$ of the BSPF, with a relatively high age (120-160 years). Scots pine communities occupy $1.9 \%$ and are represented by highly productive forests, but mostly middle-aged (75-85 years). Among them, $15 \%$ of the area are represented by young growth, mainly of artificial origin. Aspen, as a rule, has a relatively high age of 55-65 years, (the area of young growth is only $20 \%$ ) and occupies $3.8 \%$ of the total area. Siberian pine is also involved in the composition of stands of other tree species (19\%).

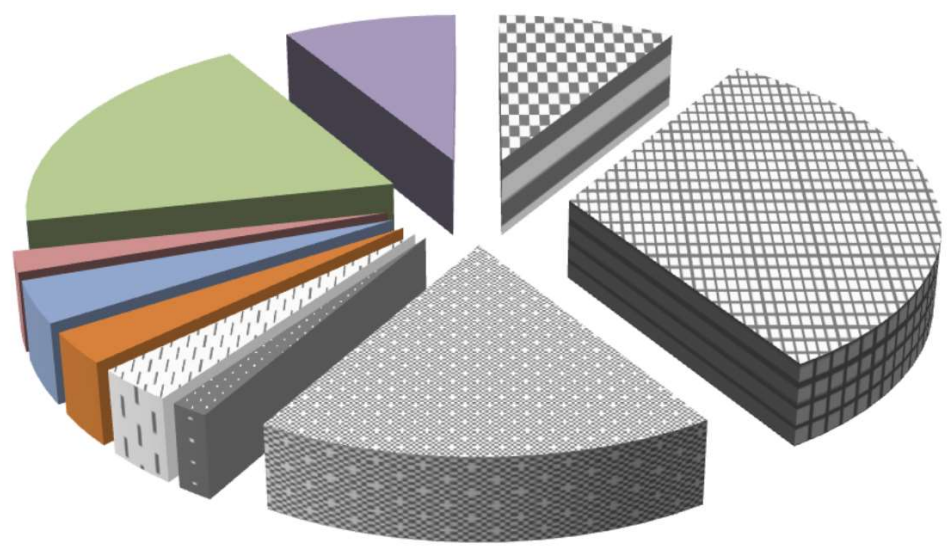

$\mathrm{MS}$ gr up to 120 years н $\mathrm{S}$ gr 120-140 years S gr more 140 years I. S gr-sw 120-140 years : S gr-sw more 140 years - Sp gr-sw

A gr - P gr $\square \mathrm{B}$ gr B gr-sw

Figure 3. Distribution of forest area of the Bazoy Siberian pine forest by forest type.

Table 2. Characteristics of stands of the Bazoy Siberian pine forest as at 2015.

\begin{tabular}{lcccccccc}
\hline Composition, \% & $\begin{array}{c}\text { Age, } \\
\text { years }\end{array}$ & Height, $\mathrm{m}$ & $\mathrm{DBH}, \mathrm{cm}$ & $\begin{array}{c}\text { Yield } \\
\text { class, } \\
\text { units }\end{array}$ & $\begin{array}{c}\text { Forest } \\
\text { type }\end{array}$ & $\begin{array}{c}\text { Relative } \\
\text { sum of basal } \\
\text { areas, units }\end{array}$ & $\begin{array}{c}\text { Trunk } \\
\text { volume, } \\
\mathrm{m}^{3} \mathrm{ha}^{-1}\end{array}$ & $\begin{array}{c}\text { Average } \\
\text { size of one } \\
\text { stand, ha }\end{array}$ \\
\hline 66S20B7P4Sp3A & $111 \pm 1$ & $24.8 \pm 0.1$ & $38.4 \pm 0.6$ & $2.3 \pm 0.2$ & $\mathrm{gr}$ & $0.64 \pm 0.02$ & $394 \pm 15$ & $12.6 \pm 4.1$ \\
77S13Sp7B3P & $131 \pm 1$ & $24.9 \pm 0.2$ & $36.6 \pm 1.0$ & $2.6 \pm 0.1$ & $\mathrm{gr}$ & $0.60 \pm 0.01$ & $356 \pm 7$ & $12.0 \pm 2.9$ \\
67S25Sp8B & $164 \pm 3$ & $25.8 \pm 0.2$ & $43.5 \pm 0.6$ & $2.8 \pm 0.1$ & $\mathrm{gr}$ & $0.60 \pm 0.02$ & $389 \pm 15$ & $9.2 \pm 2.8$ \\
44S34B22Sp & $138 \pm 2$ & $23.2 \pm 1.2$ & $35.2 \pm 2.3$ & $3.4 \pm 0.2$ & $\mathrm{gr}-\mathrm{sw}$ & $0.54 \pm 0.02$ & $286 \pm 16$ & $3.8 \pm 1.0$ \\
46S39Sp11B4P & $155 \pm 2$ & $23.1 \pm 0.5$ & $40.5 \pm 1.8$ & $3.4 \pm 0.2$ & $\mathrm{gr}-\mathrm{sw}$ & $0.51 \pm 0.04$ & $274 \pm 21$ & $4.9 \pm 1.6$ \\
71Sp19S10B & $140 \pm 5$ & $22.1 \pm 0.5$ & $28.4 \pm 1.6$ & $3.4 \pm 0.2$ & $\mathrm{gr}-\mathrm{sw}$ & $0.65 \pm 0.02$ & $236 \pm 12$ & $3.7 \pm 0.8$ \\
54A35B10P1S & $53 \pm 7$ & $19.8 \pm 2.8$ & $22.6 \pm 3.0$ & $2.1 \pm 0.4$ & $\mathrm{gr}$ & $0.68 \pm 0.04$ & $226 \pm 37$ & $4.8 \pm 1.9$ \\
41P34B14S7A & $73 \pm 9$ & $22.9 \pm 2.8$ & $30.0 \pm 3.3$ & $1.1 \pm 0.1$ & $\mathrm{gr}$ & $0.69 \pm 0.01$ & $246 \pm 33$ & $3.4 \pm 0.6$ \\
94B4Sp2S & $76 \pm 1$ & $18.7 \pm 0.3$ & $21.0 \pm 0.5$ & $5.2 \pm 1.8$ & $\mathrm{gr}-\mathrm{sw}$ & $0.61 \pm 0.01$ & $129 \pm 38$ & $2.1 \pm 0.3$ \\
70B14A8S4P4Sp & $77 \pm 1$ & $24.3 \pm 0.4$ & $28.1 \pm 0.6$ & $2.0 \pm 0.1$ & $\mathrm{gr}$ & $0.65 \pm 0.02$ & $198 \pm 9$ & $5.4 \pm 0.9$ \\
\hline
\end{tabular}

Explanations:

Composition: S - Siberian pine Pinus sibirica Du Tour, Sp - Siberian spruce Picea obovata Ledeb., A - Aspen Populus tremula L., B - Silver birch Betula pendula L. and white birch Betula pubescens Roth., P - Scots pine Pinus sylvestris L.

Forest type: gr - grassy, gr-sw - grassy-swamp 


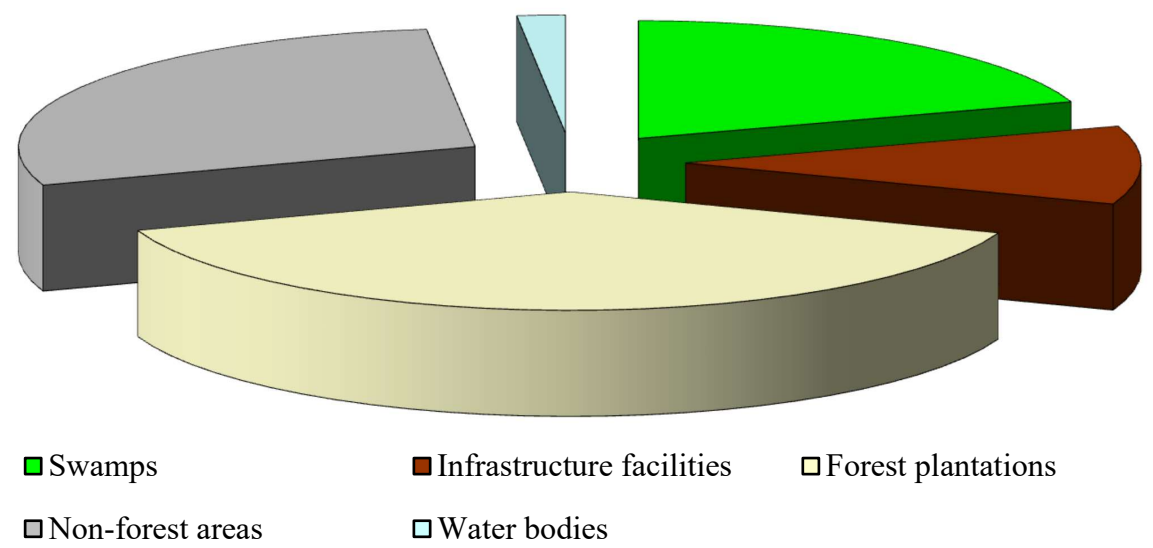

Figure 4. Distribution of non-forest land categories of the Bazoy Siberian pine forest.

Swamps occupy $2.28 \%$ of the total area of the BSPF (Figure 4) and are represented by the grassy type, with peat thickness of about $0.1 \mathrm{~m}$. Almost all swamps are overgrown with $20-30 \%$ of white birch.

Due to their linear characteristics, water bodies occupy a very small area $(0.19 \%)$ and are represented by streams (up to $1 \mathrm{~m}$ wide) and the Kinda River (3-8 m wide).

Infrastructure facilities occupy $1.22 \%$ and are represented by quarter border paths (1-2 m wide), which are mostly overgrown and require clearing. The main share in this category of lands is occupied by forest roads, which have an unpaved surface with a width of 3-5 m.

Non-forest areas occupy $3.27 \%$ of the BSPF and are represented by glades, wasteland and hayfields. On the glades, natural regeneration consists of Betula spp. $(60 \%)$ and aspen $(40 \%)$, with a stand age of 10 years, height of $3 \mathrm{~m}$ and density of 2,500 seedlings ha-1. The soil cover is predominantly grey forest soil, fresh and clayey. Wastelands differ only in that the soils are either soddy-podzolic or podzols, and the density of regeneration by pioneer hardwoods (birches and aspen) is extremely low with 500 seedlings ha-1 ${ }^{-1}$. Hayfields are of medium quality; up to $30 \%$ of them are overgrown, mainly by deciduous species, but some (10-20\%) also by Siberian spruce and Siberian pine.
Forest plantations cover over $4.49 \%$ of the BSPF. Half of the forest crops are monocultures of Scots pine aged 58-59 years, with a height of 23-26 m, a diameter of 20-28 cm and a trunk volume of 250-350 $\mathrm{m}^{3} \mathrm{ha}^{-1}$. Occasionally (in no more than $10 \%$ of the plots), in the undergrowth, along with Scots pine and Siberian spruce, up to 10-20\% consist of Siberian pine up to 1.5-2 $\mathrm{m}$ high and up to 400 seedlings ha-1. Scots pine cultures were established in 19611962, using furrowing, manual planting, a placement of $4.0 \times 0.5 \mathrm{~m}$ and a density of 4,000 saplings ha-1.

Another part of the forest plantations was established in 1991, using machine ploughing and manual planting. Half of the plots had a placement of $4.0 \times 0.5 \mathrm{~m}$ with a density of 4,000 saplings ha-1 ${ }^{-1}$ and the other half had a placement of $4.0 \times 1.0$ m with a density of 2,000 saplings ha-1. Their condition is, however, unsatisfactory due to livestock damage. Tree composition varies greatly from $80 \%$ Siberian pine, $20 \%$ silver birch with a density of 4,000 saplings ha- ${ }^{-1}$, up to $30 \%$ Siberian pine, $40 \%$ silver birch, $30 \%$ aspen with a density of 2,000 saplings ha-1. In the first case, Siberian pine has a height of $4 \mathrm{~m}$ and a diameter of $4 \mathrm{~cm}$; silver birch is $1 \mathrm{~m}$ higher than Siberian pine. In this case, about 200 seedlings ha ${ }^{-1}$ of Siberian pine undergrowth, aged 10 years and with a height of $1.5 \mathrm{~m}$, are in natural regeneration. In the 
second case, with a lower planting density, Siberian pine is $6 \mathrm{~m}$ high and $6 \mathrm{~cm}$ in diameter. However, aspen and silver birch are $10 \mathrm{~m}$ high and $12 \mathrm{~cm}$ in diameter.

\section{Discussion}

The analysis of changes in the forest cover of the BSPF over 100 years has revealed some features of its development. Like other settlements in the Tomsk region, the village of Bazoy adjoined forests with a predominance of Siberian pine and deciduous stands with the presence of Siberian pine in the second tier or in the undergrowth. As a consequence of human activity, deciduous stands were used to meet the needs for fuel, building material, etc., and felling resembled selective cutting, which contributed to the gradual creation of favourable environmental conditions for the growth and development of Siberian pine trees.

According to this scheme, Siberian pine forests were formed in Quarters 98, 99, 101 and 102 (see Figure 2). Until 1915, these quarters were covered with 15-20-yearold silver birch forests, as evidenced by the results of a survey among residents of the village of Bazoy in the 1970s (Alekseev \& Sedykh, 1976), as well as the presence of single silver birch trees aged 70-80 years as part of Siberian pine stands. In 1974, 70-80-year-old Siberian pine forests with an admixture of silver birch, Scots pine and Siberian spruce, with a relative sum of basal areas of 0.3 to 0.8 , were common in these quarters. As at 2015, Siberian pine stands were 110-125 years old. An admixture of other species was preserved, while the relative sum of basal areas became more uniform with 0.5-0.7.

The same process of Siberian pine stand formation took place in Quarter 109. Initially, it was covered with silver birch forest stands with a second tier of Siberian pine trees. Then, residents of the village of Bazoy started cutting silver birch for fuel, which led to the formation of forest com- munities with a Siberian pine tree frequency of up to $90 \%$.

However, although Siberian pine forests were established, they were also simultaneously degraded. As a result of constant human economic activities (logging, nut harvesting, picking berries and mushrooms, grazing, haying, hunting, etc.), the internal ties supporting the sustainability of forest communities are gradually disintegrating. With an increase in the intensity of anthropogenic impact due to population growth, there is also a decrease in the area of Siberian pine forests in the process of alienation of forest area for the construction of new dwellings, farm buildings, kitchen gardens, etc. This is especially evident when comparing the areas of the village of Bazoy in Figure 2.

Destruction and, accordingly, a decrease in the area of Siberian pine stands also occurred under the impact of fires caused by human activity. Thus, the Siberian pine stands in Quarters 116 and 121 died in 1915-1920 (Figure 2).

In the absence of repeated fires in these areas over time, one could expect the restoration of Siberian pine forests (according to the scheme described above) or their formation through targeted forestry activities. With repeated fires that prevent the formation of Siberian pine undergrowth, the restoration of Siberian pine forests can be extremely long or come to a halt. In particular, in the place of Siberian pine forests (Quarters 116 and 121) destroyed by fires in 1915-1920, in 1974, there were silver birch forests 55-60 years old, under the canopy of which there were only up to 300 Siberian pine seedlings ha-1 (Alekseev \& Sedykh, 1976). Periodic fires arising from neighbouring agricultural land prevented the formation of a stable undergrowth of Siberian pine and ensured the presence of silver birch in these quarters for a long time.

As of 2015, in Quarter 116, 38\% of the area of grassy silver birch forests do not have an undergrowth of Siberian pine and just represent long-term secondary com- 
munities. In the remaining area of silver birch forests, the share of Siberian pine trees in the composition of young growth is $30 \%$, with a density of 1,200 seedlings ha $^{-1}$ (limit 300-2,000 seedlings ha-1). Moreover, most often, the height of the Siberian pine is $8 \mathrm{~m}$. It is important to note that in the upper tier of communities, the share of Siberian pine trees is already $17 \%$ in $90 \%$ of the silver birch forests. As of 2015, in Quarter 121 , only $7 \%$ of the area of grassy silver birch forests do not have Siberian pine undergrowth and represent long-term secondary communities. In the remaining area of silver birch forests, the share of Siberian pine trees in the composition of young growth is $20 \%$, with a density of 800 seedlings ha-1 (limit 200-2,000 seedlings ha-1). Also, most often, the height of the Siberian pine is $8 \mathrm{~m}$. It should be noted that in the upper tier of communities, the share of Siberian pine trees is already $15 \%$ in $77 \%$ of the silver birch forests. Therefore, even without human intervention, the process of Siberian pine stand formation is ongoing.

In Quarter 115 and partially adjacent to it, as clearly seen in Figure 2, Siberian pine stands had been destroyed in a fire. Most of this degraded area was replanted with Scots pine in 1958-1959. Since these sites are occupied by communities of other tree species, for an indefinitely long time, it will be impossible to grow Siberian pine stands on them. A visual examination showed that these forest crops, due to the inconsistency of the habitat conditions (too high trophicity for Scots pine), are of low commercial value.

The main factor in deforestation is agriculture. Large-scale global reconstruction of the forest cover from 800 to 1700 showed that about 5 million $\mathrm{km}^{2}$ of natural vegetation (mainly forests) were converted to agricultural land (Pongratz et al., 2008). An analysis of satellite images of 1975 and 2000 for sub-Saharan Africa indicates a $57 \%$ increase in agricultural land or former natural vegetation, which has declined by $21 \%$ during this period, with almost 5 mil- lion hectares of forest and non-forest natural vegetation being lost annually (Brink \& Eva, 2009). In Africa, Asia and South America, there has been a decrease in the area of forests, which are cut down and cleared for plantation production (Campbell \& du Toit, 1994). For example, in southwestern Uganda, from 1973 to 2010, forest area, including protected forests, decreased due to agricultural development and population growth (Twongyirwe et al., 2011; Rosell et al., 2017). At the same time, meadow communities also undergo transformation (Majaliwa et al., 2010). Deforestation processes even occur in protected forests; a study of the dynamics of forest cover in a protected area in Jamaica from 1942 to 2010 showed that the main factor in deforestation is the density of roads (Newman et al., 2014). In Ethiopia, agricultural land and forests show a relatively equal amount of net change $(+36.7 \%$ and $-37.9 \%$, respectively), but opposite trends (Deribew \& Dalacho, 2019). However, as established by Amsalu et al. (2007) in view of the decrease in soil fertility, there is a tendency to transfer arable land to pastures and to increase plantation cultivation of eucalyptus in private forests. This economic impetus has led to the expansion of forest plantings $(20.5 \%)$ and the restoration of previously degraded territories (Minta et al., 2018). In China, also after 1980, in most traditional agrarian regions there, was a decrease in cultivated land area (Liu \& Tian, 2010).

As a strategy for the restoration of degraded areas after intensive agriculture, for example in Ethiopia (Bishaw, 2001), social forestry practices have been developed. Until the late 1960s, when a reforestation program was launched in the villages, knowledge spread "from top to bottom" (Mgeni, 1992). Subsequently, it turned out that farmers are good experts in regeneration and tree care (Kajembe, 1994). A good example is shown in Macias \& Dryjer (2004) where the dynamics of forest cover in the vicinity of Poznan was studied. During the period of 1830-2004, the forested 
area increased mainly due to afforestation in previously deforested areas and rationing of logging.

\section{Conclusions}

The dynamics of the forest cover of the BSPF for the period from 1915 to 1974 is characterised by a significant increase in the area of Siberian pine stands (by $16.3 \%$ ). The main reason for this is the establishment of Siberian pine forests by cutting the upper tier from birch. In the period from 1974 to 2015, there was a tendency to reduce the area of Siberian pine stands (by 6.0\%), resulting in the appearance of non-forest lands (glades, wastelands, hayfields). Glades and wastelands are the result of either logging or, more likely, areas of non-renewed conflagrations and places of mass reproduction of phytophages of the past years. Haymaking is a direct consequence of the transfer of forest territory to non-forest areas, with the aim of conducting agricultural subsidiary farming. It has been established that the main factors in the dynamics of forest cover are felling and forest fires, of which the latter periodically arise and lead to the death of Siberian pine forests.

Our study clearly shows the possibility of sustainable forest management on communal lands, forming the most socially and ecologically acceptable forests near villages. It is also important to note that forests with the predominance of Siberian pine are the most indigenous type of vegetation cover and the best way to sequester carbon over a long period, which is important against the background of a changing climate.

\section{References}

Alekseev, Yu.B., Sedykh, V.N. 1976. Development of near-settlement Siberian pine forests. (Развитие припоселковых кедровников). - Improving the Efficiency of Forestry in Western Siberia, 133-178. (In Russian).
Amsalu, A., Stroosnijder, L., de Graaf, J. 2007. Long-term dynamics in land resource use and the driving forces in the Beressa watershed, highlands of Ethiopia. - Journal of Environmental Management, 83, 448-459.

Bishaw, B. 2001. Deforestation and land degradation in the Ethiopian highlands: a strategy for physical recovery. - Northeast African Studies, 8(1), 7-26.

Brink, A.B., Eva, H.D. 2009. Monitoring 25 years of land cover change dynamics in Africa: a sample based remote sensing approach. Applied Geography, 29(4), 501-512.

Campbell, B.M., du Toit, R.F. 1994. Vegetation patterns and the influence of small-scale farmers in a semi-arid savanna area in Zimbabwe. - Kirkia, 15, 10-32.

Da Ponte, E., Mack, B., Wohlfart, C., Rodas, O., Fleckenstein, M., Oppelt, N., Dech, S., Kuenzer, C. 2017. Assessing forest cover dynamics and forest perception in the Atlantic forest of Paraguay, combining remote sensing and household level data. - Forests, 8(10), 389.

Danchenko, A.M., Bekh I.A. 2010. The Siberian Pine Forests of Western Siberia. Tomsk, Tomsk State University. 424 pp. (In Russian with English summary).

Debkov, N. 2019. Accelerated formation of Siberian pine (Pinus sibirica Du Tour) stands: a case study from Siberia. - Journal of Forest Science, 65, 291-300.

Debkov, N.M. 2014. The Siberian Pine Forests Near Settlements of South of the West Siberian Plain: History and Current State, Recommendations for Sustainable Management (On the Example of the Tomsk Region). (Припоселковые кедровники юга Западно-Сибирской равнины: история и современное состояние, рекомендации по устойчивому управлению (на примере Томской области)). Moscow, WWF Russia. 52 pp. (In Russian).

Deribew, K.T., Dalacho, D.W. 2019. Land use and forest cover dynamics in the North-eastern Addis Ababa, central highlands of Ethiopia. Environmental Systems Research, 8, 8 .

Digitization of vegetation. 2011. Digitization of vegetation. (Оцифровка растительности). [WWW document]. - URL http://www. easytrace.com/digitization/vegetation_ru. [Accessed 6 March 2020]. (In Russian).

Dramstad, W.E. 2009. Spatial metrics - useful indicators for society or mainly fun tools for landscape ecologists? - Norwegian Journal of Geography, 63, 246-254.

Haines-Young, R., Chopping, M. 1996. Quantifying landscape structure: a review of landscape indices and their application to forested landscapes. - Progress in Physical Geography, 20, 418-445.

Jadin, I., Vanacker, V., Hoang, H.T.T. 2013. Drivers of forest cover dynamics in smallholder farming systems: the case of northwestern Vietnam. - AMBIO, 42, 344-356. 
Kajembe, G.C. 1994. Indigenous management systems as a basis for community forestry in Tanzania: a case study of Dodoma urban and Lushoto districts. - Tropical Resource Management Paper, 6. Wageningen, Wageningen Agricultural University. 211 pp.

Keranen, K., Malone, L. 2017. Instructional Guide for the ArcGIS Imagery Book. Redlands, Esri Press. 262 pp. [WWW document]. - URL https://downloads.esri.com/LearnArcGIS/ pdf/instructional-guide-for-the-arcgisimagery-book.pdf. [Accessed 3 March 2020].

Kottek, M., Grieser, J., Beck, C., Rudolf, B., Rubel F. 2006. World map of the Köppen-Geiger climate classification updated. - Meteorologische Zeitschrift, 15, 259-263.

Krivets, S.A., Bisirova, E.M., Chernova, N.A., Pats, E.N., Kerchev, I.A. 2014. A complex description of Siberian stone pine forests biodiversity at the southern border of their outreach in West Siberia. - Tomsk State University Journal of Biology, 2(26), 130-150. (In Russian with English summary).

Kundu, S.N. 2017. Forest cover dynamics in south east Asia evidenced from MODIS data. Research \& Reviews: Journal of Ecology and Environmental Sciences, 5(1), 2-7.

Lambin, E.F., Geist, H.J., Lepers, E. 2003. Dynamics of land use and cover change in tropical regions. - Annual Review of Environment and Resources, 28, 205-241.

Lewis, S.L., Maslin, M.A. 2015. Defining the anthropocene. - Nature, 519, 171-180.

Li, H., Wu, J. 2004. Use and misuse of landscape indices. - Landscape Ecology, 19(4), 389-399.

Lin, S., Jiang, Y., He, J., Ma, G., Xu, Y., Jiang, H. 2017. Changes in the spatial and temporal pattern of natural forest cover on Hainan Island from the 1950s to the 2010s: implications for natural forest conservation and management. - PeerJ, 5, e3320.

Liu, M., Tian, H. 2010. China's land cover and land use change from 1700 to 2005: estimations from high resolution satellite data and historical archives. - Global Biogeochemical Cycles, 24(3), GB3003.

Loran, C., Kienast, F., Bürgi, M. 2018. Change and persistence: exploring the driving forces of long-term forest cover dynamics in the Swiss lowlands. - European Journal of Forest Research, 137, 693-706.

Luoga, E.J., Witkowski, E.T.F., Balkwill, K. 2005. Land cover and use changes in relation to the institutional framework and tenure of land and resources in eastern Tanzania miombo woodlands. - Environment, Development and Sustainability, 7, 71-93.

Macias, A., Dryjer, M. 2010. Forest cover dynamics in the city of Poznań from 1830 to 2004. Quaestiones Geographicae, 29(3), 47-57.
Majaliwa, J.G.M., Twongyirwe, R., Nyenje, R., Oluka, M., Ongom, B., Sirike, J., Mfitumukiza, D., Azanga, E., Natumanya, R., Mwerera, R., Barasa, B. 2010. The effect of land cover change on soil properties around Kibale National Park in South Western Uganda. - Applied and Environmental Soil Science, article ID 185689.

Mgeni, A.S.M. 1992. Farm and community forestry (village afforestation) program in Tanzania: Can it go beyond lipservice? - Ambio, 21, 426-430.

Minta, M., Kibret, K., Thorne, P., Nigussie, T., Nigatu, L. 2018. Land use and land cover dynamics in Dendi-Jeldu hilly-mountainous areas in the central Ethiopian highlands. Geoderma, 314, 27-36.

Mitchell, A. 2005. The ESRI Guide to GIS Analysis, Volume 2: Spatial Measurements and Statistics. Redlands, Esri Press. 252 pp.

Newman, M.E., McLaren, K.P., Wilson, B.S. 2014. Assessing deforestation and fragmentation in a tropical moist forest over 68 years; the impact of roads and legal protection in the Cockpit Country, Jamaica. - Forest Ecology and Management, 315, 138-152.

Pongratz, J., Reick, C., Raddatz, T., Claussen, M. 2008. A reconstruction of global agricultural areas and land cover for the last millennium. Global Biogeochemical Cycles, 22(3), GB3018.

Reddy C.S., Jha C.S., Dadhwal, V.K. 2013. Assessment and monitoring of long-term forest cover changes in Odisha, India using remote sensing and GIS. - Environmental Monitoring and Assessment, 185(5), 4399-4415.

Rosell, S., Olvmo, M., Holmer, B. 2017. Cultivated land - a scarce commodity in a densely populated rural area in South Wollo, Ethiopia. - Journal of Land Use Science, 12, 252-270.

Selvaraj, M., Das Kangabam, R., Kumar, P., Suganthi, P., Govindaraju, M. 2013. Assessment of forest cover dynamics through remote sensing and GIS for Pacha-Malai reserve forest of Tamil Nadu, India. - International Journal of Remote Sensing \& Geoscience, 2(5), 46-52.

Skole, D.L., Tucker, C.J. 1993. Tropical deforestation and habitat fragmentation in the Amazon: satellite data from 1978 to 1988. Science, 260(5116), 1905-1910.

Thayamkottu, S., Joseph, S. 2018. Tropical forest cover dynamics and carbon emissions contribution of remote sensing and data mining techniques. - Tropical Ecology, 59(4), 555-563.

Twongyirwe, R., Majaliwa, J.G.M., Ebanyat, P., Tenywa, M.M., Sheil, D., Heist, M.V., Oluka, M., Kumar, L. 2011. Dynamics of forest cover conversion in and around Bwindi impenetrable forest, Southwestern Uganda. - Journal of Applied Sciences and Environmental Management, 15(1), 189-195. 
United Nations Declaration. 2000. United Nations Millennium Declaration 2000: Millennium Summit of the United Nations. New York, United Nations. 9 pp. [WWW document]. - URL https://www.un.org/ruleoflaw/ files/United \%20Nations \% 20Millennium $\% 20$ Declaration.pdf. [Accessed 31 January 2020].
Yang, S., Mountrakis, G. 2017. Forest dynamics in the U.S. indicate disproportionate attrition in western forests, rural areas and public lands. PLoS ONE, 12(2), e0171383.

Received May 30, 2020, revised December 04, 2020, accepted December 04, 2020 